\title{
POT1 wt Allele
}

National Cancer Institute

\section{Source}

National Cancer Institute. POT1 wt Allele. NCI Thesaurus. Code C107656.

Human POT 1 wild-type allele is located in the vicinity of $7 q 31.33$ and is approximately 108 $\mathrm{kb}$ in length. This allele, which encodes protection of telomeres protein 1 , is involved in the positive regulation of telomerase. 